\title{
Teaching Vocabulary in Chinese Universities: What and How?
}

\author{
Liang Li \\ English Department, Hebei Radio \& TV University \\ 481 He Ping West Road, Shijiazhuang 050071, China \\ Tel: 86-311-8705-3646 E-mail: liliang@hebnetu.edu.cn \\ Xuan Zhang \\ English Department, Hebei Radio \& TV University \\ 481 He Ping West Road, Shijiazhuang 050071, China \\ E-mail: zhangxuan@hebnetu.edu.cn
}

\begin{abstract}
One of the major tasks of tertiary English teachers is to enlarge the students' vocabulary size; therefore, it is necessary for the teachers to explore the answers to two major questions concerning vocabulary instruction. What vocabulary should we focus on? And how can we teach vocabulary in the classroom? In order to answer these two questions, this essay reviews the previous western research in the area. By so doing it divides English vocabulary into four groups high frequency words, academic vocabulary, technical vocabulary and low frequency words - and points out the favorable learning sequence and different focuses. It also provides the teachers with a series of vocabulary learning methodologies as well as the underlined theories.
\end{abstract}

Keywords: Vocabulary instruction, Vocabulary size, Teaching methodologies

\section{Introduction}

With the globalization of the trade and culture in China, English as a global language (Nunan, 2003) plays a more and more important role in Chinese daily life and grasping the language has become one of the essential abilities of most Chinese graduates. As fundamental components of the language, English vocabulary as well as its grammar is of critical importance to language learners (Lewis, 1997; Zimmerman, 1997). Since Chinese students have systematically learnt English grammar but not vocabulary in their high schools, lexical development becomes the major task in their tertiary English study. Therefore, it is necessary for tertiary English teachers to explore the answers to two major questions concerning vocabulary instruction. What vocabulary should we focus on? And how can we teach vocabulary in the classroom?

\section{What vocabulary should we focus on?}

How many words are there in English? If we use the notion of word family, which consists of "a basic word, inflected forms, and transparent deviations" (Nation \& Waring, 1997, p.7), Webster's Third New International Dictionary, as the largest non-historical English dictionary, contains "around 114,000 word families excluding proper names" (Nation, 2001, p.6). However, people cannot realistically know all the words in a dictionary. The vocabulary size of an educated native speaker is "around 20,000 word families" (Nation, 2001, p.9). However, most English learners cannot grasp and nor do they need this size of vocabulary to communicate effectively in a wide variety of contexts.

English teachers are advised to teach their learners a comparatively small amount of vocabulary according to the learners' specific needs (Nation, 2001). In other words, teachers need to guide their learners to spend time on the vocabulary that will bring the most benefits for learning. In order to help L2 teaching and learning, Coxhead and Nation (2001) have divided English vocabulary into four categories: high frequency words, academic vocabulary, technical vocabulary and low frequency words. English teachers need to know which group of vocabulary items they should focus on.

Many western researchers (e.g. Coxhead, 2000; Nation, 2001; Nation \& Newton, 1997; Sökmen, 1997) agree that the 
high frequency 2,000 words, accounting for more than $85 \%$ of the running words in any text, are the first choice for English learners and deserve considerable time and attention. Therefore, as it is suggested, tertiary English teachers should make sure that their students have grasped these words before moving to next level of vocabulary. They can base their teaching on Michael West's (1953) General Service List of English Words (GSL), which covers 90\% tokens of fiction texts, $75 \%$ of nonfiction texts and $76 \%$ of academic ones (Coxhead, 2000). It is the basis of the high frequency word list contributed by Nation (1996). However, Williams (2004) argues for a "frequency paradox" - since the high frequency 2,000 words are common in any text, it is the rest less than $20 \%$ running words that convey the unique meaning of one specific text.

The academic vocabulary list is suitable for next stage of vocabulary instruction. As Nation and Newton (1997) suggest, academic vocabulary is for learners who "intend to do academic study or wish to read newspapers" (p.239). For example, the Academic Word List (AWL), developed by Coxhead (2000), only contains 570 word families but covers $12.0 \%$ running words of commerce, $9.3 \%$ of arts, $9.4 \%$ of law and $9.1 \%$ of science. Also, "67\% of the word families in the AWL occur in 25 or more of the [all] 28 subject areas, and $94 \%$ occur in 20 or more" (Coxhead, 2000, p.222). Considering most college students in China are educated to be specialists in one subject area, the AWL is a valuable tool to provide them with access to academic English sources. Moreover, according to frequency, the AWL has been divided into 10 sub-lists so it is convenient for English teachers to set short-term learning goals for their students (Coxhead, 2000).

Technical vocabulary, which consists of approximately 1,000 words and covers $5 \%$ of the total texts, is useful within a specialized field but differs from one subject area to another (Coxhead \& Nation, 2001). In China, many majors learn specific English (e.g. automobile English) and these technical words, together with the words in the AWL, satisfy the students' particular needs.

Low frequency vocabulary is for learners who "intend to use English for social purposes, for occupations that do not require the reading of academic text, or for reading novels and popular magazines" (Nation \& Newton, 1997, p.239). For example, as a cleaner, one needs to know the words like mop, broom, sink, hand base, and block. However, because these words may occur only once or twice in readings during a long period of time (Coxhead \& Nation, 2001) and usually learners can guess their meanings from the context (Nation \& Newton, 1997), it is not worthwhile for English teachers as well as college students to spend too much time on them.

To summarize, Coxhead and Nation's (2001) division answers the question which vocabulary to focus on, and provides Chinese English teachers and English examination designers with a very useful guide. They may want to help the students learn the 2,000 high frequency words and the 570 academic words first, because these words cover nearly $90 \%$ tokens in most academic readings (Coxhead \& Nation, 2001). When supplemented by proper nouns and technical vocabulary, the students can recognize $95 \%$ running words, which guarantee their reading comprehension (Coxhead \& Nation, 2001).

\section{How can we teach vocabulary in the classroom?}

As L2 learners, Chinese students need not grasp as many English words as native speakers, but they still feel frustrated when memorizing or learning thousands of words. Therefore, it is helpful to teach students some vocabulary learning techniques and there are many western studies concerning vocabulary-teaching methodologies as well (e.g. Coady, 1997; Hulstijn, 1997; Nation \& Newton, 1997; Sökmen, 1997).

\subsection{Explicit teaching and vocabulary learning}

Sökmen (1997) focuses on explicit teaching and employs three theories to illustrate vocabulary instruction. Firstly, according to lexico-semantic theory, "the human lexicon is, therefore, believed to be a network of associations, a web-like structure of interconnected links" (Sökmen, 1997, p.241). Based on similar or different word meanings, teachers can help their students to establish the links between the to-be-learned word and words already known. Strategies like semantic feature analysis, semantic mapping, ordering or classifying words and pictorial schemata can all be used to set up memory traces between each word. However, Nation and Newton (1997) argue that the way of word storage cannot determine the way of word acquisition and learning the related words together is likely to cause confusion. Therefore, teachers should be cautious of using these strategies. It is more suitable to use them when teaching individual word or when reviewing words.

Secondly, theories of human memory highlight the significance of recalling words, which can lead to better retention. Usually rehearsal at increasingly longer intervals has better results for long-term storage than rehearsal at regular intervals, which is better than "massive rehearsal at infrequent intervals" (Hulstijn, 1997, p.219; Sökmen, 1997). If students recall the word with its associated words, their learning will be more effective (Hulstijn, 1997). Moreover, grasping a word is more than remembering the form and meaning. In order to learn its different semantic features, collocations and other information, "a range of 5-16 encounters" is necessary (Sökmen, 1997, p.241). Therefore, on the one hand, teachers can relax their students by making them know that they need more encounters to remember a word; 
on the other hand, teachers can intentionally create more opportunities for their students to recall words.

Thirdly, the dual coding theory of human memory suggests the need to create verbal and nonverbal memory links to enhance the effects of vocabulary learning. That is to say, teachers can use pictures, illustrations or diagrams to assist instruction. Also they can relate the words to current events, past experiences or anything else in real life.

\subsection{Communicative activities and vocabulary learning}

Nation and Newton (1997) regard communicative activities as efficient in learning vocabulary. Communicative activities provide a platform for students to carry out meaningful conversations. Through these activities, experts may scaffold novices to learn new words, new items may occur several times, and novices may have the chance to use the words productively. There are a number of different activities, for example, split information activities, ranking information activities and ask-and-answer activities. As Nation and Newton (1997) explain, psychologically most students can be brave enough to expose errors or express misunderstandings to their interlocutors or group members. Hulstijn (1997) adds that language production may facilitate students' comprehension.

Nation and Newton (1997) also provide teachers with three guidelines of how to choose and place vocabulary in communicative activities. Firstly there should be few new words in the instructions so as not to hinder the progress of the task. Secondly unfamiliar vocabulary should occur within meaningful contexts, which enables learners to guess the word meaning. Thirdly if the vocabulary is very difficult, pre-explanation or a gloss is necessary. In addition, Nation and Newton (1997) encourage teachers to incorporate split information activities and ranking information activities: the former elicits an evenly shared conversation and attracts students' attention on word forms; the latter prompts meaning negotiation and deep comprehension.

\subsection{Extensive reading and vocabulary learning}

Coady (1997) asserts that if students are familiar with the 3,000 most frequent words, extensive reading can be an effective way for them to acquire vocabulary. Eskey (2005) also argues that if readers encounter less than one unknown word in every twenty words, they will not feel frustrated and are likely to continue reading. Therefore, choosing reading materials with appropriate difficulty level is of vital importance to enlarge the student's vocabulary: the texts should be somewhat challenging but cannot exceed the reader's lexical competence too much.

It is also important to choose the right reading materials. Chinese English teachers are likely to encourage their students to read English novels after class. However, from Coxhead's (2000) research, we can see that only $1.4 \%$ running words in English novels are academic vocabulary. That is to say, reading novels is not a beneficial way to improve students' academic vocabulary.

Finally, interest is the best teacher. Teachers should allow students to choose their own readings in order to make sure that the students are enthusiastic with their reading.

\section{Implications}

One of the main objectives of tertiary English courses in China is to enlarge students' vocabulary. Therefore, it is of vital importance for tertiary English teachers to make clear their vocabulary teaching focus and to grasp a series of vocabulary teaching methodologies. Based on the above review, we would like to provide the following suggestions:

First and most important, teachers need to consider their teaching focus and sequence. The high frequency 2,000 words (e.g. Nation, 1996), which are the starting point of any English learning, should be adopted as the first choice and given enough attention. The academic vocabulary list (e.g. the AWL devised by Coxhead, 2000), which is the basis of academic English, can be used to facilitate students' academic study. Together with the high frequency vocabulary and technical vocabulary, it provides enough knowledge for students to study in any specific area. However, the low frequency words, usually in novels and popular magazines, are not worthwhile to teach.

Moreover, teachers need to flexibly employ different methods in class to facilitate vocabulary learning. They can use semantic strategies to help students build up links between individual words in their memory. They can intentionally elicit students to recall words during class. They can also use visual aids or relate words to social events to enhance students' memory. Communicative activities (e.g. split information activities, ranking information activities and ask-and-answer activities) are another effective vocabulary teaching strategy, but teachers need to choose appropriate words and contexts. Extensive reading can help vocabulary learning as well, but teachers need to control the difficulty level of materials, provide the right readings and involve students' active participation. Of course, there are many other ways of teaching vocabulary and teachers can also develop their own methods according to the features of their classes.

\section{Conclusion}

Vocabulary instruction, as well as grammar, is of critical importance, especially in Chinese universities. Therefore, as college English teachers, we need to answer two major questions concerning vocabulary teaching: what vocabulary should we focus on? And how can we teach vocabulary in the classroom? By reviewing recent western research, we 
suggest teachers teach vocabulary in a sequence according to learners' needs. Also we have listed a range of vocabulary learning techniques, and discussed the theories behind them and their learning contexts. Hopefully by so doing we can prompt more thinking and more effective teaching strategies on vocabulary instruction.

\section{References}

Coady, J. (1997). L2 vocabulary acquisition through extensive reading. In Coady, J. \& Huckin, T. (Eds.), Second language vocabulary acquisition. New York: Cambridge University Press. pp.225-237

Coxhead, A. \& Nation, P. (2001). The specialized vocabulary of English for academic purposes. In Flowerdew, J. \& Peacock, M. (Eds.), Research perspectives on English for academic purposes. Cambridge: Cambridge University Press. pp.252-267

Coxhead, A. (2000). A new academic word list. TESOL Quarterly, 34, 213-238.

Eskey, D. E. (2005). Reading in a second language. In Hinkel, E. (Ed.), Handbook of research in second language teaching and learning. Mahwah, New Jersey: Lawrence Erlbaum Associates. pp. 563-580

Hulstijn, J. (1997). Mnemonic methods in foreign language vocabulary learning: Theoretical considerations and pedagogical implications. In Coady, J. \& Huckin, T. (Eds.), Second language vocabulary acquisition. New York: Cambridge University Press. pp.203-224

Lewis, M. (1997). Pedagogical implications of the lexical approach. In Coady, J. \& Huckin, T. (Eds.), Second language vocabulary acquisition. New York: Cambridge University Press. pp.255-270

Nation, I. S. P. (1996). Vocabulary lists. Wellington, N.Z.: Victoria University of Wellington, English Language Institute.

Nation, I. S. P. (2001). Learning vocabulary in another language. Cambridge; New York: Cambridge University Press.

Nation, P. \& Newton, J. (1997). Teaching vocabulary. In Coady, J. \& Huckin, T. (Eds.), Second language vocabulary acquisition. New York: Cambridge University Press. pp.238-254

Nation, P. \& Waring, R. (1997). Vocabulary size, text coverage and word lists. In Schmitt, N. \& McCarthy, M. (Eds.), Vocabulary: Description, acquisition and pedagogy. Cambridge; New York: Cambridge University Press. pp.6-19

Nunan D. (2003). The impact of English as a global language on educational policies and practices in the Asia-Pacific region. TESOL Quarterly, 37, pp.589-613.

Sökmen, A. J. (1997). Current trends in teaching second language vocabulary. In Schmitt, N. \& McCarthy, M. (Eds.), Vocabulary: Description, acquisition and pedagogy. Cambridge; New York: Cambridge University Press. pp.237-257

Williams, E. (2004). Literacy studies. In Davies, A. \& Elder, C. (Eds.), The handbook of applied linguistics. Blackwell Publishing Ltd.. pp. 576-603

Zimmerman, C. B. (1997). Historical trends in second language vocabulary instruction. In Coady, J. \& Huckin, T. (Eds.), Second language vocabulary acquisition. New York: Cambridge University Press. pp.5-19 